\section{Household food insecurity and excess weight/ obesity among Brazilian women and children: a life-course approach}

\author{
Insegurança alimentar e excesso de peso/ \\ obesidade entre mulheres e crianças brasileiras: \\ uma abordagem para o curso da vida
}

\author{
Inseguridad alimentaria y exceso de peso/ \\ obesidad entre mujeres y niños brasileños: \\ un enfoque para el transcurso de la vida
}

Michael Maia Schlüssel 1

Antonio Augusto Moura da Silva 2

Rafael Pérez-Escamilla ${ }^{3}$

Gilberto Kac ${ }^{1}$

\footnotetext{
${ }^{1}$ Instituto de Nutrição Josué de Castro, Universidade Federal do Rio de Janeiro, Rio de Janeiro, Brasil.

2 Universidade Federal do Maranhão, São Luís, Brasil. 3 Yale School of Public Health, Yale University, New Haven, U.S.A.

Correspondence G. Kac

Departamento de Nutrição Social e Aplicada, Instituto de Nutrição Josué de Castro, Universidade Federal do Rio de Janeiro.

Av. Carlos Chagas Filho 373, CCS, Bloco J, 2 o andar, Rio de Janeiro, RJ 21941-902, Brasil. gilberto.kac@gmail.com
}

\begin{abstract}
Household food insecurity (HFI) may increase obesity risk, but results are not consistent across the life course or between developed/underdeveloped settings. The objective of this paper is to review findings from previous analyses in Brazil among adult women, female adolescents, and children up to five. Data were derived from the 2006 Brazilian Demographic and Health Survey. Associations between HFI (measured with the Brazilian Food Insecurity Scale) and excess weight/obesity were investigated through Poisson regression models. While severe HFI was associated with obesity risk among adult women (PR: 1.49; 95\%CI: 1.17-1.90), moderate HFI was associated with excess weight among female adolescents (PR: 1.96; 95\%CI: 1.18-3.27). There was no association between HFI and obesity among children (either boys or girls). The nutrition transition in Brazil may be shaping the differential deleterious effect of HFI on body fat accumulation across the life course; the association is already evident among female adolescents and adult women but still not among children.
\end{abstract}

Nutritional Transition; Food Security; Nutritional Status; Life Cycle Stages

\section{Resumo}

A insegurança alimentar (IA) pode aumentar o risco de obesidade, mas os resultados não são consistentes para todos os estágios do curso da vida e entre países desenvolvidos/subdesenvolvidos. O objetivo deste artigo é revisar os resultados de análises anteriores com dados brasileiros de mulheres adultas, adolescentes do sexo feminino e crianças até cinco anos. Utilizaram-se dados da Pesquisa Nacional de Demografia e Saúde 2006. Associações entre IA, medida pela Escala Brasileira de Insegurança Alimentar e excesso de peso/obesidade foram investigadas por modelos de regressão de Poisson. IA grave está associada com obesidade entre mulheres adultas (RP: 1,49; IC95\%: 1,17-1,90) e IA moderada com excesso de peso entre adolescentes do sexo feminino (RP: 1,96; IC95\%: 1,18-3,27). Não houve associação entre IA e obesidade em crianças de ambos os sexos. É possível que o processo de transição nutricional no Brasil modele o efeito deletério da IA no acúmulo de gordura corporal ao longo do curso da vida, sendo a associação evidente entre adolescentes e adultas, mas ainda não entre crianças.

Transição Nutricional; Segurança Alimentar e Nutricional; Estado Nutricional; Estágios do Ciclo de Vida 


\section{Introduction}

Household food insecurity (HFI) is related to poverty, which in turn has traditionally been linked to undernutrition. However, the nutrition paradox proposed over fifteen years ago ${ }^{1}$ considered the hypothesis of an association between HFI and excess weight, a possibility that since then has been at least partially supported by empirical evidence predominantly generated in the USA 2 .

Research shows that women living with HFI are more likely to present excess weight when compared to their food-secure counterparts. There is also growing evidence of a positive association between HFI and obesity among adolescents. For children, support of an association between HFI and weight status has been mixed, and there is sparse evidence for the adult male population. Furthermore, there is little evidence that HFI promotes increased weight gain over time because most data were derived from crosssectional studies 3,4,5,6.

With obesity rates rising worldwide and the eradication of HFI far beyond reach, a complete understanding of the relationship between these two apparently paradoxical conditions is essential for the development, implementation, and expansion of effective policies and programs 7.

The goal of this study is to present a summary of results on the association between HFI and excess weight/obesity, using data from the 2006 Brazilian Demographic and Health Survey (DHS), following a life-course approach, examining data from adult women, female adolescents, and children under five $8,9,10$.

\section{Methods}

Three different sub-samples derived from the 2006 Brazilian DHS were analyzed: adult women (18-49 years); female adolescents (15-19 years); and children of both sexes (0-60 months). The Brazilian DHS is a nationally representative cross-sectional household survey with a complex sampling design. The DHS collected data from childbearing-age women, including mothers and their children aged 0-5 years 11,12. Detailed information on study design and data collection can be found in the publications used as the basis for the summary results presented here 8,9,10.

The study outcomes were excess weight/ obesity, defined in different ways for each subset. For children, body mass index/age z-scores (BMI-Z) were calculated according to the World Health Organization (WHO) growth reference standards 13 . BMI-Z can measure either excess or insufficient weight for a certain length or height and is expressed as sex- and age- (in months) specific z-scores. Obesity was defined as BMI-Z > 2 standard deviations (SD) ${ }^{8}$. For female adolescents aged 15-18 years, the WHO age-adjusted BMI growth charts were used to classify nutritional status. The $85^{\text {th }}$ percentile was defined as the cut-off for excess weight. For adolescents aged 19 years we defined excess weight as BMI $\geq$ $25 \mathrm{~kg} / \mathrm{m}^{2} 9$. For adult women, obesity was defined as $\mathrm{BMI} \geq 30 \mathrm{~kg} / \mathrm{m}^{2} 10$.

HFI level (security, mild insecurity, moderate insecurity, severe insecurity) was the key independent variable and was measured with the previously used and extensively validated $\mathrm{Bra}$ zilian Food Insecurity Scale (EBIA). EBIA is an adaptation of the US Household Food Security Survey Module (US-HFSSM), developed during the early 1990s and first fielded in the 1995 US Current Population Survey. The detailed description of the adaptation and validation of the EBIA scale can be found elsewhere 14,15. The EBIA is composed of 15 dichotomous (yes/no) questions, which evaluate food insecurity experiences representing different levels of food insecurity. Each household is assigned a summative food insecurity score based on the number of affirmative answers to the scale items. Households were classified either as food secure (HFI score $=0$ ), mildly food insecure (score $=1-5$ ), moderately food insecure (score $=6$-10), or severely food insecure $($ score $=11-15)$.

Statistical analyses comprised the prevalence distribution of HFI and excess weight/obesity for each of the age groups. Subsequently, associations between HFI and the outcomes were investigated through adjusted prevalence ratios (PR) with $95 \%$ confidence intervals (CI) using multivariate Poisson regression models. The following confounders were considered in the multivariate analysis (i) children: geographic region of the household (North, Northeast, Southeast, South, Midwest), area of residence (urban, rural), family income quartiles, mother's skin color (white, black, brown, yellow, indigenous), maternal schooling (0-4, 5-8, $\geq 9$ years), maternal smoking (yes, no), maternal marital status (single/ widowed/divorced or married/cohabiting), sex, age, birth order, and number of children aged 0-60 months living in the household; (ii) female adolescents: geographic region of the household, area of residence, per capita family income (log-transformed), skin color, years of schooling, smoking, marital status, number of people living in the household, and age; and (iii) adult women: geographic region of the household, family income quartiles, skin color, years of schooling, marital status, and age. These covariates were selected based on theoretical and empirical con- 
siderations and allow for direct comparison between studies.

Analyses on obesity prevalence and the Poisson regression model for children are new. All other estimates presented in the paper have been reported previously 8,9,10. All estimates were weighted, and standard errors were corrected to account for the complex sampling design by "svy" commands in Stata version 10.1 (Stata Corp., College Station, USA).

\section{Results}

The weighted prevalence of any level of food insecurity among households with children was $48.6 \%$ (mild $=29.4 \%$, moderate $=13.5 \%$, and severe $=5.7 \%$ ). The corresponding value for households with female adolescents was $41.3 \%$ $($ mild $=26.9 \%$, moderate $=9.6 \%$ and severe $=$ $4.8 \%$ ), while for households with adult women it was $39.8 \%$ (mild $=26.1 \%$, moderate $=8.9 \%$ and severe $=3.8 \%$ ) (Figure 1 ).

Prevalence of BMI-Z $>2$ SD for the sample of children was $7.2 \%$ (males $=7.7 \%$ and females $=$ $6.6 \%$ ). Excess weight was found in $21.9 \%$ of female adolescents (overweight $=12.9 \%$ and obe- sity $=9 \%$ ), and for the adult female sample, obesity prevalence was $16.7 \%$ (Table 1 ).

The relationship between HFI and obesity was not significant for children (Figure 2). Among female adolescents, the likelihood of excess weight was 1.96 times higher among those with severe HFI when compared to their food-secure counterparts (Figure 3). Among adult women, the likelihood of obesity was 1.49 times higher among those with moderate HFI when compared to their food-secure counterparts (Figure 4).

\section{Discussion}

Following a life-course approach, this paper shows that Brazilian adult women living in moderately food-insecure households had a $49 \%$ higher risk of being obese, and female adolescents living in severely food-insecure households were almost twice as likely to show excess weight when compared to their food-secure counterparts. No association was shown between HFI and obesity among Brazilian children (either boys or girls) aged 0-60 months.

The study has some limitations, namely the inability to ascertain the temporal direction of

Figure 1

Prevalence of household food insecurity (HFI) among Brazilian children (both sexes) aged 0-60 months, female adolescents (15-19 years), and adult women (18-49 years). 2006 Brazilian Demographic and Health Survey *.

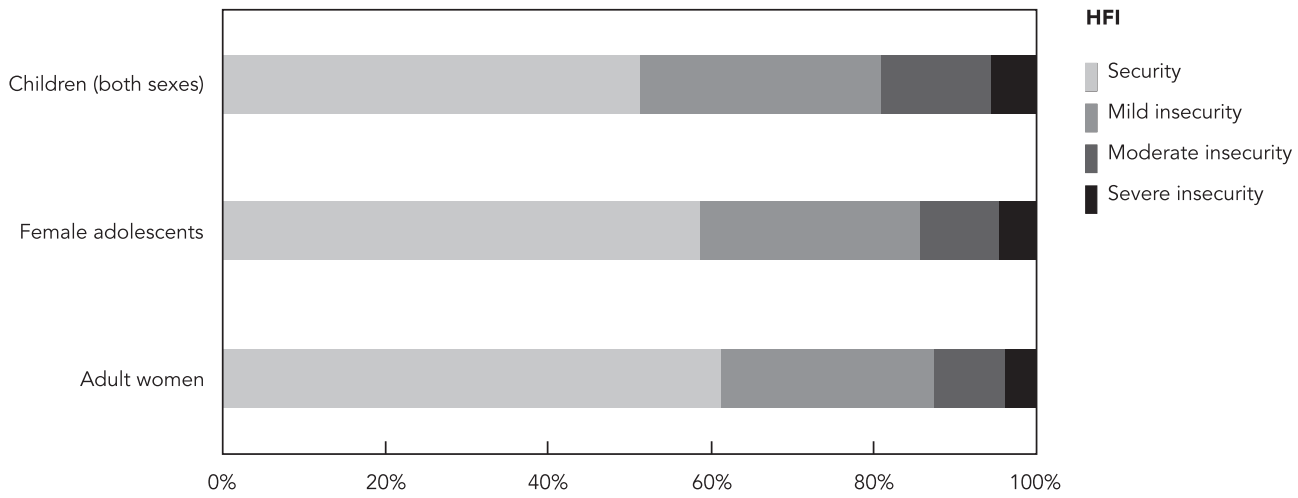

\footnotetext{
* Estimates were weighted and standard errors were corrected to take the complex sampling design into account. Sample size and $95 \%$ confidence intervals $(95 \% \mathrm{Cl}$ ) for prevalence of HFI: Children: Security ( $\mathrm{n}=1,710 ; 95 \% \mathrm{Cl}: 47.5-55.4)$, mild HFI ( $\mathrm{m}=944$; 95\%Cl: 26.3-32.7), moderate HFI ( $n=481$; 95\%Cl: 11.3-16.0), severe HFI ( $n=298 ; 95 \% \mathrm{Cl}: 4.6-7.0)$; Female adolescents: Security ( $n=887 ; 95 \% \mathrm{Cl}$ : 53.2-64.0), mild HFI $(n=374 ; 95 \% \mathrm{Cl}: 22.0-32.4)$, moderate $\mathrm{HFI}(n=175 ; 95 \% \mathrm{Cl}: 7.0-12.9)$, severe $\mathrm{HFI}$ ( $n=93 ; 95 \% \mathrm{Cl}: 3.1-7.4)$; Adult women: Security $(\mathrm{n}=6,039 ; 95 \% \mathrm{Cl}: 59.0-63.3)$, mild HFI ( $n=2,610 ; 95 \% \mathrm{Cl}: 24.4-27.8)$, moderate $\mathrm{HFI}(\mathrm{n}=1,032 ; 95 \% \mathrm{Cl}: 8.0-9.9)$, severe $\mathrm{HFI}(\mathrm{n}=545 ; 95 \% \mathrm{Cl}: 3.3-4.5)$.

Note: figure constructed with data from Kac et al. 8,9 and Velásquez-Meléndez et al. 10.
} 
Prevalence of body mass index/age in z-score (BMI-Z) > 2 standard deviations (SD), for children (0-60 months), excess weight in female adolescents (15-19 years), and obesity in adult women (18-49 years) and respective $95 \%$ confidence intervals (95\%Cl). 2006 Brazilian Demographic and Health Survey *.

\begin{tabular}{|c|c|c|c|c|}
\hline & \multirow[t]{2}{*}{$\mathbf{N}$} & \multicolumn{3}{|c|}{ BMI-Z >2 SD **/Excess weight $* \star \star / O b e s i t y ~ \#$} \\
\hline & & $\mathbf{n}$ & $\%$ & $95 \% \mathrm{Cl}$ \\
\hline Children (both sexes) ** & 3,433 & 277 & 7.20 & $5.89-8.78$ \\
\hline Children (boys) ** & 1,750 & 157 & 7.73 & $5.88-10.11$ \\
\hline Children (girls) ${ }^{\star \star}$ & 1,683 & 120 & 6.63 & $5.03-8.68$ \\
\hline 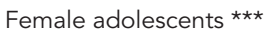 & 1,529 & 299 & 21.88 & $17.94-26.42$ \\
\hline Adult women \# & 10,226 & 1,780 & 16.74 & $15.54-18.01$ \\
\hline
\end{tabular}

* Estimates were weighted and standard errors were corrected to take the complex sampling design into account;

** BMI-Z > 2 SD measure excess weight for a certain length or height;

$\star \star \star$ Excess weight was defined as $\mathrm{BMI} \geq 85^{\text {th }}$ percentile of WHO reference for adolescents aged $15-18$ and $\geq 25 \mathrm{~kg} / \mathrm{m}^{2} \mathrm{for}$ those aged 19 years;

\# Obesity was defined as $\mathrm{BMI} \geq 30 \mathrm{~kg} / \mathrm{m}^{2}$ for adults.

Note: table constructed with data from Kac et al. ${ }^{9}$ and Velásquez-Meléndez et al. 10.

Figure 2

Prevalence ratio * of body mass index/age z-score (BMI-Z) $>2$ SD according to household food insecurity (HFI) levels for Brazilian children (aged 0-60 months) of both sexes ( $n=3,433)$. 2006 Brazilian Demographic and Health Survey **

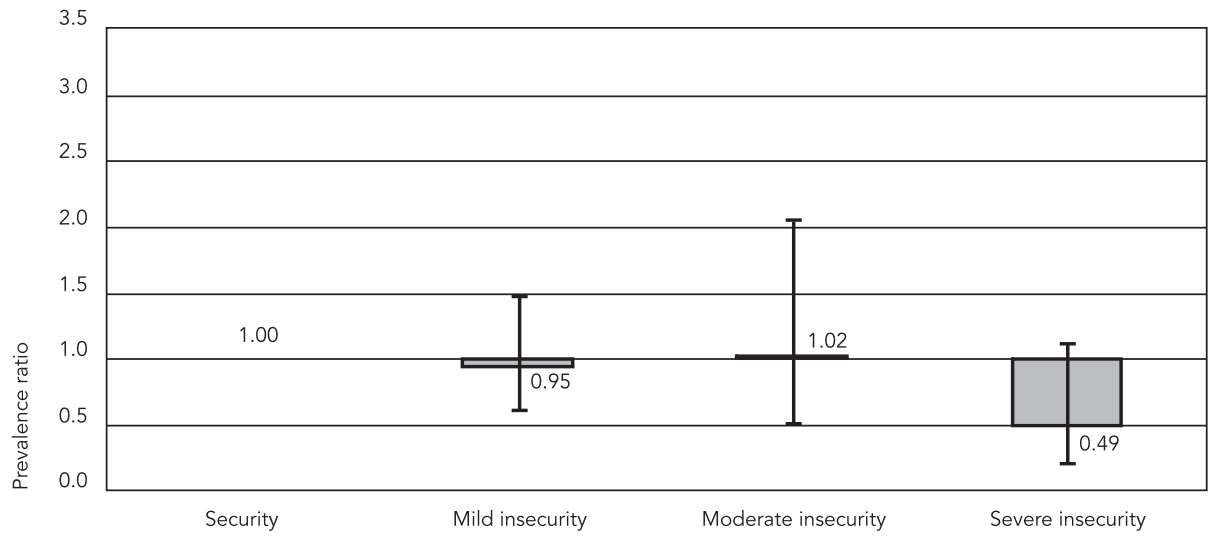

* Prevalence ratios were adjusted for geographic region of the household, area of residence (urban, rural), income quartiles, mother's self-reported skin color, maternal schooling, maternal smoking, maternal marital status, sex, age, birth order, and number of children $0-5$ years living in the household;

** Estimates were weighted and standard errors were corrected to take the complex sampling design into account. 
Figure 3

Prevalence ratio * of excess weight ** according to household food insecurity (HFI) levels for Brazilian female adolescents $(n=1,529) .2006$ Brazilian Demographic and Health Survey ${ }^{\star \star \star}$.

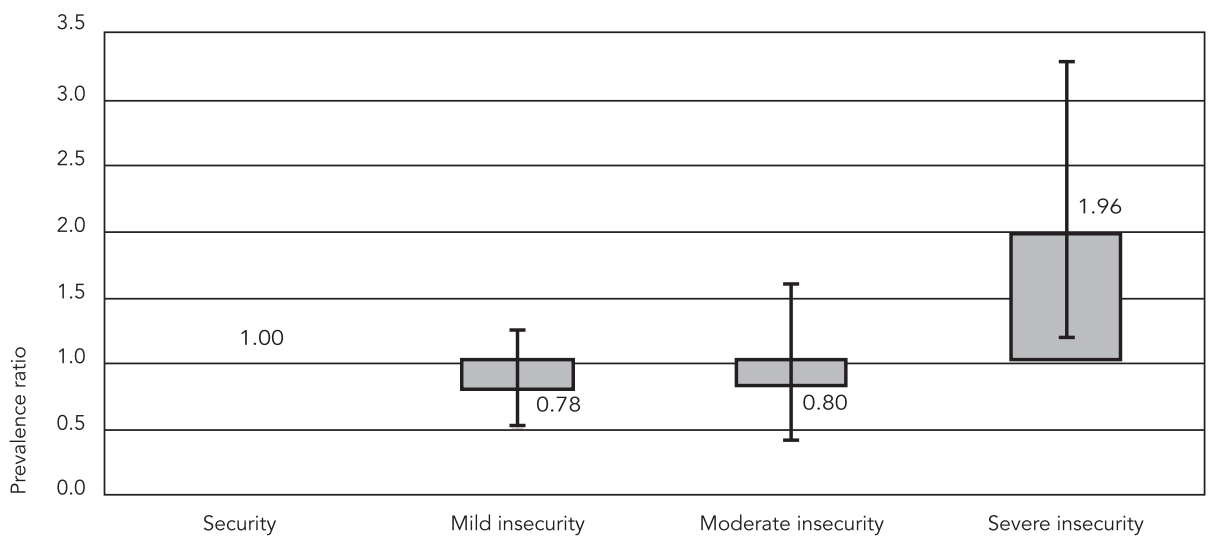

* Prevalence ratios were adjusted for self-reported skin color, schooling, area of residence (urban, rural), geographic region, per capita family income (log-transformed), smoking, marital status, number of persons living in the household, and age in years;

** Excess weight was defined as $\mathrm{BMI} \geq 85^{\text {th }}$ percentile of the WHO reference for adolescents aged $15-18$ and $\geq 25 \mathrm{~kg} / \mathrm{m}^{2}$ for those aged 19 years;

*** Estimates were weighted and standard errors were corrected to take the complex sampling design into account. Note: figure constructed with data from Kac et al. 9 .

Figure 4

Prevalence ratio * of obesity ** according to household food insecurity (HFI) levels for Brazilian adult women (18-49 years) ( $n=10,226) .2006$ Brazilian Demographic and Health Survey ***.

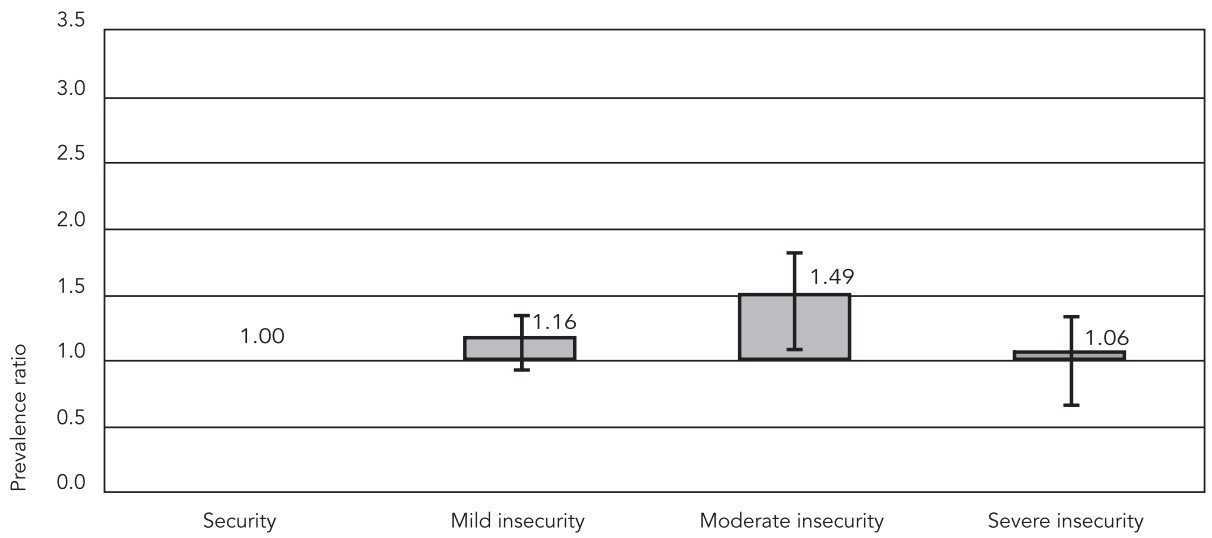

* Prevalence ratios were adjusted for skin color, schooling, geographic region, income quartiles, age, and marital status;

** Obesity was defined as $\mathrm{BMI} \geq 30 \mathrm{~kg} / \mathrm{m}^{2}$;

*** Estimates were weighted and standard errors were corrected to take the complex sampling design into account. Note: figure constructed with data from Velásquez-Meléndez et al. 10. 
associations between HFI and excess weight/ obesity (a characteristic of cross-sectional design). In addition, since population-based surveys with complex samples have broad and general goals, important potential mediators or confounders were not measured (e.g. self-rated health, dietary intake, alcohol consumption, and physical activity). However, estimates for adult women and female adolescents remained statistically significant after adjusting for several known potential confounders, including geographic region of the household, family income, skin color, schooling, marital status, and age.

The results agree with those of previous studies using U.S. population samples, in which mild HFI was associated with obesity in adult women $16,17,18$. However, in other low and middle-income countries experiencing early stages of the nutrition transition, such as Trinidad and Tobago 19 and Colombia 20 , HFI was associated with undernutrition rather than obesity. This could be due to the fact that Brazil is at a more advanced stage in the nutrition transition, with higher prevalence rates for obesity than for underweight in poor women 21 .

A possible explanation for the difference in the level of HFI at which adolescent and adult women are affected (i.e. severe HFI for adolescents and moderate HFI for adults) lies in the physiological changes related to puberty which make adolescents more resistant to body fat accumulation. By contrast, adult women's obesity risk increased with moderate HFI. In addition parents may also protect children and adolescents from some of the harmful effects of HFI. It is also possible that strong concerns with body image, common among young Brazilian women 22,23, may protect them from the obesogenic influence of HFI until the problem becomes so severe that they can no longer cope without changing lifestyle behaviors, which lead to body fat accumulation.

To explain the paradoxical association between HFI and excess weight/obesity in this study, we hypothesize that poorer families are purchasing high-fat and energy-dense foods, following classic economic consumer theories 24,25 . Furthermore, due to their limited access to food, when any foods are available these individuals may overeat or even eat foods they normally would not have access to in an attempt to compensate for periods of scarcity ${ }^{3}$, despite their ability to identify healthy foods 26 . In this sense, the paradox would be directly related to the way different countries experience the nutrition transition; only when this process reaches a stage at which energy-dense foods become available at affordable prices, HFI becomes a risk factor for excess weight/obesity.

Moreover, Brazil's current stage of nutrition transition may also help explain the lack of association between HFI and obesity among young children. It has been suggested that the dynamics regarding the occurrence of a shift from undernutrition to obesity tend to follow a path that starts among adults, followed by adolescents, and only later affects children 27 . This nutrition transition pattern has been documented previously in the Brazilian population by studies using data from the most important nationally representative surveys in the last two decades 21,27 . The possible effect of HFI on obesity in children may constitute a feature of a very advanced stage of the nutrition transition that Brazil has still not reached. However, this hypothesis has not been confirmed in the U.S. population. Alternatively, the relatively high-energy requirements per unit of body weight may protect children against the negative influence of HFI on obesity.

In conclusion, the nutrition transition in Brazil may be shaping the differentially deleterious effect of HFI on body fat accumulation over the life course. This may explain why the association between HFI and excess weight/obesity is still not evident among Brazilian children but is found among female adolescents and adult women. 


\section{Resumen}

La inseguridad alimentaria (IA) puede aumentar el riesgo de obesidad, pero los resultados no son consistentes en todas las fases del transcurso de la vida y entre países desarrollados/subdesarrollados. El objetivo de este artículo es revisar los resultados de los análisis anteriores con los datos brasileños de: mujeres adultas, adolescentes del sexo femenino y niños de hasta cinco años. Se utilizaron datos del Estudio Nacional de Demografía y Salud 2006. Asociaciones entre la IA, medida por la Escala Brasileña de Inseguridad Alimentaria y exceso de peso/obesidad se investigaron mediante modelos de regresión de Poisson. Una IA grave está asociada con obesidad entre mujeres adultas [RP: 1,49; IC95\%: 1,17-1,90] y una IA moderada con exceso de peso entre adolescentes del sexo femenino [RP: 1,96; IC95\%: 1,18-3,27]. No hubo asociación entre la IA y la obesidad en niños de ambos sexos. Es posible que el proceso de transición nutricional en Brasil modele el efecto deletéreo de la IA en el acúmulo de grasa corporal a lo largo del transcurso de la vida, existiendo una asociación evidente entre adolescentes y adultas, sin embargo, todavía no entre niños.

Transición Nutricional; Seguridad Alimentaria;

Estado Nutricional; Estagios del Ciclo de Vida

\section{Contributors}

M. M. Schlüssel planned the study, analyzed the data, wrote the paper, and approved the final manuscript. A. A. M. Silva analyzed the data, wrote the paper, and approved the final manuscript. R. Pérez-Escamilla planned the study, wrote the paper and approved the final manuscript. G. Kac planned the study, analyzed the data, wrote the paper, and approved the final manuscript.

\section{References}

1. Dietz WH. Does hunger cause obesity? Pediatrics 1995; 95:766-7.

2. Kursmark M, Weitzman M. Recent findings concerning childhood food insecurity. Curr Opin Clin Nutr Metab Care 2009; 12:310-6.

3. Dinour LM, Bergen D, Yeh MC. The food insecurity-obesity paradox: a review of the literature and the role food stamps may play. J Am Diet Assoc 2007; 107:1952-61.

4. Eisenmann JC, Gundersen C, Lohman BJ, Garasky $\mathrm{S}$, Stewart SD. Is food insecurity related to overweight and obesity in children and adolescents? A summary of studies, 1995-2009. Obes Rev 2011; 12:e73-83.

5. Larson NI, Story MT. Food insecurity and weight status among U.S. children and families: a review of the literature. Am J Prev Med 2011; 40:166-73.

6. Franklin B, Jones A, Love D, Puckett S, Macklin J, White-Means S. Exploring mediators of food insecurity and obesity: a review of recent literature. J Community Health 2012; 37:253-64.

7. Tanumihardjo SA, Anderson C, Kaufer-Horwitz M, Bode L, Emenaker NJ, Haqq AM, et al. Poverty, obesity, and malnutrition: an international perspective recognizing the paradox. J Am Diet Assoc 2007; 107:1966-72.
8. Kac G, Schlüssel MM, Pérez-Escamilla R, Velásquez-Melendez G, da Silva AAM. Household food insecurity is not associated with BMI for age or weight for height among Brazilian children aged 0-60 months. Plos One 2012; 7:e45747.

9. Kac G, Velásquez-Meléndez G, Schlüssel MM, Segall-Côrrea AM, Silva AA, Pérez-Escamilla R. Severe food insecurity is associated with obesity among Brazilian adolescent females. Public Health Nutr 2012; 15:1854-60.

10. Velásquez-Meléndez G, Schlüssel MM, Brito AS, Silva AA, Lopes-Filho JD, Kac G. Mild but not light or severe food insecurity is associated with obesity among Brazilian women. J Nutr 2011; 141:898-902.

11. Instituto Brasileiro de Geografia e Estatística. Pesquisa Nacional por Amostra de Domicílios: 2006. v. 27. Rio de Janeiro: Instituto Brasileiro de Geografia e Estatística; 2007.

12. Ministério da Saúde. Pesquisa Nacional de Demografia e Saúde da Criança e da Mulher - PNDS 2006. Brasília: Ministério da Saúde; 2008.

13. WHO Multicentre Growth Reference Study Group. WHO Child Growth Standards: length/height-forage, weight-for-age, weight-for-length, weight-forheight and body mass index-for-age: methods and development. Geneva: World Health Organization; 2006. 
14. Pérez-Escamilla R, Segall-Côrrea AM, KurdianMaranha L, Sampaio F, Marin-Leon L, Panigassi G. An adapted version of the U.S. Department of Agriculture Food Insecurity module is a valid tool for assessing household food insecurity in Campinas, Brazil. J Nutr 2004; 134:1923-8.

15. Melgar-Quinonez H, Nord M, Pérez-Escamilla R, Segall-Côrrea AM. Psychometric properties of a modified US household food security survey module in Campinas, Brazil. Eur J Clin Nutr 2008; 62:665-73.

16. Sarlio-Lahteenkorva S, Lahelma E. Food insecurity is associated with past and present economic disadvantage and body mass index. J Nutr 2001; 131:2880-4.

17. Townsend MS, Peerson J, Love B, Achterberg C, Murphy SP. Food insecurity is positively related to overweight in women. J Nutr 2001; 131:1738-45.

18. Adams EJ, Grummer-Strawn L, Chavez G. Food insecurity is associated with increased risk of obesity in California women. J Nutr 2003; 133:1070-4.

19. Gulliford MC, Mahabir D, Rocke B. Food insecurity, food choices, and body mass index in adults: nutrition transition in Trinidad and Tobago. Int J Epidemiol 2003; 32:508-16.

20. Isanaka $S$, Mora-Plazas $M$, Lopez-Arana $S$, Baylin A, Villamor E. Food insecurity is highly prevalent and predicts underweight but not overweight in adults and school children from Bogota, Colombia. J Nutr 2007; 137:2747-55.
21. Kac G, Velásquez-Meléndez G. A transição nutricional e a epidemiologia da obesidade na América Latina. Cad Saúde Pública 2003; 19 Suppl 1:S4-5.

22. Monteiro CA, Benicio MHD'A, Conde WL, Popkin BM. Shifting obesity trends in Brazil. Eur J Clin Nutr 2000; 54:342-6.

23. Kakeshita IS, Almeida SS. The relationship between body mass index and body image in Brazilian adults. Psychol Neurosci 2008; 28:103-7.

24. Drewnowski A, Specter SE. Poverty and obesity: the role of energy density and energy costs. Am J Clin Nutr 2004; 79:6-16.

25. Finkelstein EA, Strombotne KL. The economics of obesity. Am J Clin Nutr 2010; 91:1520S-4S.

26. Freedman DA, Bell BA. Access to healthful foods among an urban food insecure population: Perceptions versus reality. J Urban Health 2009; 86:825-38.

27. Monteiro CA, Conde WL, Popkin BM. Is obesity replacing or adding to undernutrition? Evidence from different social classes in Brazil. Public Health Nutr 2002; 5:105-12.

Submitted on 10/Sep/2012

Approved on 12/Sep/2012 